\title{
The Pious life of Empress Helena, Constantine the Great's Mother, in The Light of Socrates of Constantinople and Sozomen
}

$\mathrm{H}^{\mathrm{s}}$ elena, the famously pious mother of emperor Constantine the Great, is one of the most celebrated empresses of the Roman Empire. Hans A. Pohlsander even saw her as one of the most remarkable women in all of ancient history ${ }^{1}$; in Leslie Brubaker's opinion, the augusta Helena was an important symbol in Byzantium $^{2}$, who had supplied the model for elite female appropriation of sanctity ${ }^{3}$. Her holiness was viewed by subsequent generations as being due to her piety ${ }^{4}$. In Rome, as is well known, pietas was not only one of the fundamental virtues, but also belonged to the most important ideas of the state. According to Roman beliefs, pietas guaranteed divine blessing and the ensuing good fortune to the Roman people 5 . Helena's reputation was, on the one hand, linked to her son's conversion to Christianity (which marked the beginning of the Christianization of the empire's state structures), and on the other hand - to the legend of her discovering the relics of the True Cross. Her worship has developed throughout the universal Church over time, and she has been recognized worthy of veneration in both the East and West. Unfortunately, however, the source data regarding her accomplishments are rather modest ${ }^{6}$. Perhaps this is why so few monographs exploring her

\footnotetext{
${ }^{1}$ H.A. Pohlsander, Helena. Empress and Saint, Chicago 1995, p. 1.

${ }^{2}$ L. Brubaker, Memories of Helena. Patterns in Imperial Female Matronage in the Fourth and Fifth Centuries, [in:] Women, Men and Eunuchs. Gender in Byzantium, ed. L. James, London-New York 1997, p. 52.

${ }^{3}$ L. Brubaker, Memories of Helena..., p. 64.

${ }^{4}$ According to Hartmut Leppin (Von Constantin dem Grossen zu Theodosius II. Das christliche Kaisertum bei den Kirchenhistorikern Socrates, Sozomenus und Theodoret, Göttingen 1996, p. 58): auch die Kaisermutter Helena, mit deren Namen die Auffindung des Kreuzes verbunden ist, wird nicht als Heilige geschildert, mag auch ihre fromme Demut noch so gerühmt warden.

${ }^{5}$ Cf. M.P. Charlesworth, The Virtues of a Roman Emperor. Propaganda and the Creation of Belief, PBA 23, 1937, p. 105-133; J.R. FEARs, The cult of Virtues and Roman Imperial Ideology, [in:] ANRW, vol. II.17.2, Berlin-New York 1981, p. 864sqq; A. Wallace-Hadrill, The Emperor and His Virtues, Hi 30, 1981, p. 298-323.

${ }^{6}$ Among the most important sources related to Helena are: Eusebius CaEsariensis, Vita Constantini, III, 25-47, ed. F. Winkelmann, Berlin-New York 2008 [= GCS, 7], p. 94-104; Ambrosius
} 
life and achievements exist in the general scholarly literature ${ }^{7}$ let alone in Polish-language scholarship, where only a handful publications have been devoted to Constantine's mother'.

The important sources referring to Helena notably include the Ecclesiatical history by Socrates of Constantinople. On the other hand, the Ecclesiatical history by Sozomen - while only slightly younger - is generally considered to be of little use due to its secondary nature? ${ }^{9}$. It is true that Sozomen, writing his Ecclesiatical history, relied heavily on Socrates' work ${ }^{10}$; still, did he merely duplicate the latter's depiction of the empress? I will try to clarify this point in the present paper.

Mediolanensis, De obitu Theodosi, 43-48, ed. A. KotŁowska, K. Ilski, Poznań 2008, p. 42-47; Paulinus Nolanus, Epistulae, 31, ed. G. De Hartel, Vindobonae 1894 [= CSEL, 29], p. 267-275; Rufinus Aquileiensis, Historia ecclesiastica, X, 7-8, ed. E. Schwartz, T. Mommsen, F. Winkelmann, Berlin 1999 [= GCS, Neue Folge, 6], p. 969-971; Socrates, Historia ecclesiastica, I, 17, ed. G.C. Hansen, Berlin 1995 [= GCS, Neue Folge, 1], p. 55-57; Theodoretus Cyrensis, Historia ecclesiastica, I, 18, ed. L. Parmentier, G.Ch. Hansen, Berlin-New York 2009 [= GCS, Neue Folge, 5], p. 63-65; Gelasius Cyzicenus, Historia ecclesiastica, ed. M. Heinemann, G. Loeschcke, Leipzig 1918 [= GCS, 28].

${ }^{7}$ Cf. A.-M. Roulllon, Sainte Hélène, Paris 1908; R. Couzard, Sainte Hélène d’après l'histoire et la tradition, Paris 1911; J. Maurice, Sainte Hélène, Lille 1927; H.H. Lauer, Kaiserin Helena. Leben und Legenden, München 1967; J.W. Drijvers, Helena Augusta, the Mother of Constantine the Great and the Legend of Her Finding of the Cross, Leiden-New York-København-Köln 1992; H.A. PoHLSANDER, Helena....

${ }^{8}$ Cf. A. Szymański, Św. Helena cesarzowa, Poznań 1933; E. Zwolski, Helena, matka Konstantyna Wielkiego w świetle historii, ZNKUL 5, 1962, p. 53-76; H. Fros, Święta Helena, Kraków 1995; M.B. LeszkA, Helena - matka Konstantyna Wielkiego, MW 2002, 4, p. 30-32; Z.A. BrzozowsKA, Ideał chrześcijańskiego władcy - św. św. Konstantyn i Helena w kulturze duchowej i politycznej Bizancjum (337-843 r.), Thi 36/37, 2009, p. 152-164.

${ }^{9}$ Cf. S. Borgehammar, How the Holy Cross was found. From Event to Medieval Legend, Stockholm 1991, p. 29; L. Wojciechowsкi, Drzewo przenajszlachetniejsze. Problematyka Drzewa Krzyża w chrześcijaństwie zachodnim (IV-połowa XVII w.). Od legend do kontrowersji wyznaniowych i piśmiennictwa specjalistycznego, Lublin 2003, p. 4.

${ }^{10}$ The relation between the texts by Sozomen and Socrates has been discussed a number of times. Cf. G.C. Hansen, Einleintung, [in:] Sozomenus, Historia ecclesiastica, ed. I. Bidez, G.Ch. Hansen, Berlin 1995 [= GCS, Neue Folge, 4], p. XLV-XLVII; G.F. Chesnut, The First Christian Histories. Eusebius, Socrates, Sozomen, Theodoret, and Evagrius, Paris 1977, p. 205; G. SABBAH, Introduction, [in:] Sozomène, Histoire Ecclésiastique, vol. I, ed. B. Grillet, G. SABbah, Paris 1983 [= SC, 306], p. 59; F. Young, From Nicaea to Chalkedon, London 1983, p. 32; T.D. BARnes, Athanasius and Constantius. Theology and Politics in the Constantinian Empire, Cambridge 1993, p. 206; T. URBaInCzyк, Observations on the differences between the Church Histories of Socrates and Sozomen, Hi 46, 1997, p. 355-356. P. van Nuffelen (Un Héritage de Paix et de Piété. Étude sur les histoires ecclésiastiques de Socrate et de Sozomène, Leuven-Paris-Dudley 2004) devoted a whole monograph to the analysis of differences and similarities between the two Ecclesiastical histories. According to P. JANIsZEWSKI (Żywioly w stużbie propagandy, czyli po czyjej stronie stoi Bóg. Studium klęsk i rzadkich fenomenów przyrodniczych u historyków Kościoła w IV i V w., [in:] Chrześcijaństwo u schyłku starożytności. Studia źródłoznawcze, ed. T. Derda, E. Wipszycka, vol. III, Kraków 2000, p. 153), Sozomen aimed to write a text that would compete with Socrates' account, closer to the canons of classical literature and to the tastes of the 
Socrates ${ }^{11}$ starts his narrative about Helena ${ }^{12}$, the mother of emperor Constantine, from the information about Drepanum being raised to the status of a city and renamed (in her honour) Helenopolis ${ }^{13}$; this proves Constantine's love and

intellectual circles of Constantinople. In my opinion, however, the dependence of Sozomen's work on Socrates's text was due to the former's involvement in conflicts inside the Church, which peaked after the Second Council of Ephesus (Latrocinium Ephesinum) in 449. His Ecclesiastical history, dedicated to emperor Theodosius II, may have been an attempt to persuade the ruler to change his ecclesiastical policy; but if it was to be successful, it had to be written quickly. Hence, Sozomen simply reinterpreted and broadened the existing work by Socrates. Cf. S. BRALEWSKI, Obraz papiestwa w historiografii kościelnej wczesnego Bizancjum, Łódź 2006, p. 274-278.

${ }^{11}$ It was long believed that one of Socrates's key sources was the (only partially extant) Ecclesiastical history by Gelasios of Caesarea. Such a conjecture was expressed by A. GLAs (Die Kirchengeschichte des Gelasios von Kaisareia, die Vorlage für die beiden letzten Bücher der Kirchengeschichte Rufinus, Leipzig-Berlin 1914, p. 79-82). It was presented as a certainty by F. Winkelmann (Das Problem der Rekonstruktion der Historia ecclesiastica des Gelasius von Caesarea, FF 10, 1964, p. 311-314; IDEM, Untersuchungen zur Kirchengeschichte des Gelasios von Kaisareia, Berlin 1966 [= SDAWB.KSLK, 3]; IDEM, Charakter und Bedeutung der Kirchengeschichte des Gelasios von Kaisareia, BF 1, 1966, p. 346-385), and later upheld, among others, by T.D. BARNEs (Athanasius and Constantius..., p. 89); J.H.W.G. Liebeschuetz (Ecclesiastical Historians on Their Own Times, SP 34, 1993, p. 151-163); G.C. Hansen (Einleintung, [in:] Socrates, Historia ecclesiastica, p. XLV-XLIX; IDEM, Mutmassungen über die Kirchengeschichte des Sokrates, ZAC 3, 1999, p. 278-285); M. WALlRaff (Der Kirchenhistoriker Sokrates. Untersuchungen zu Geschichtsdarstellung, Methode und Person, Göttingen 1997, p. 137). However, according to T. URBAINCZYк (Socrates of Constantinople. Historian of Church and State, Michigan 1997, p. 51) if Socrates had access to Gelasius' work (...) it is unclear why he should acknowledge Rufinus but not Gelasius; besides, [i]t also seems odd that Socrates should decide to use Rufinus if the original Greek version [Gelasius of Caesarea] had been available (p. 102). Similar doubts were expressed by P. van Nuffelen (Gélase de Césarée, Un compilateur du cinquième siècle, BZ 95.2, 2002, p. 627), in whose opinion the historical Gelasius of Caesarea was not the author of the Ecclesiastical history attributed to him; rather, it was written by someone impersonating him - a Pseudo-Gelasius of sorts - as late as in the second half of the $5^{\text {th }}$ century (p. 630, 634).

${ }^{12}$ H.A. Pohlsander (Helena..., p. 1) saw in her one of the most remarkable women in all of ancient history. According to P. Maraval (Socrate de Constantinople, Histoire ecclésiastique, ed. G.C. Hansen, P. Périchon, P. Maraval, Paris 2004 [= SC, 477], p. 175, fn. 5), when writing the chapter devoted to Helena, Socrates relied mostly on the accounts of Rufinus of Aquileia (Rufinus Aquileiensis, Historia ecclesiastica, X, 7-8, p. 969-971) and Eusebius of Caesarea (Eusebius CAESARIEnsis, Vita Constantini, III, 25-47, p. 94-104). J.W. Drijvers (Helena Augusta..., p. 3) suggests that as metropolitan bishop of Palestine, Eusebius no doubt accompanied her on her travels through his province.

${ }^{13}$ Socrates, Historia ecclesiastica, I, 17, 1, p. 55. Neither Eusebius nor Rufinus mention Drepanum at all. Procopius (De aedificiis, V, 2, 1, ed. H.B. Dewing, G. Downey, London 1940, p. 320) remarks that Helena was born in the town, which Socrates does not include in his account. Pohlsander, like many other researchers, subscribes to the view that Drepanum was indeed Helena's birthplace (H.A. Pohlsander, Helena..., p. 3-5), but J.W. Drijvers (Helena Augusta..., p. 12) cautions that other places besides Drepanum have been suggested: Naissus, Caphar Phacar in Mesopotamia, Edessa, Trier and even Colchester. As in the case of Drepanum, none of these places can be seriously considered Helena's place of origin. Cf. also: V. VATchкova, (Saint) Helena of Sofia. The Evolution of the Memory of Saint Constantine's Mother, [in:] The Reception of Byzantium in European Culture since 1500, ed. D. Smyth, P. Marciniak, Farnham 2016, p. 81-91. According to Philostorgius (Historia ecclesi- 
respect towards her. Socrates's account also indicates the empress's close relationship with God: she received a number of prophetic visions ${ }^{14}$, which she understood as summoning her to travel to Jerusalem ${ }^{15}$. There, she started the zealous search for the sepulchre of Christ, which was, at the same time, the place of His resurrection ${ }^{16}$. The empress encountered a number of difficulties - which Socrates summarised with the sentence it was not easy for her $(\delta v \sigma \chi \varepsilon \rho \tilde{\omega} \varsigma)^{17}$ - but with the help of God she eventually did find the True Cross $^{18}$. As far as the sepulchre is concerned, the empress seems not to have had any major problems locating it, since Christians had treated this place ${ }^{19}$ with great respect ${ }^{20}$. The emperor's mother

astica, ed. I. Bidez, F. Winkelmann, Berlin 1981 [= GCS, 21], p. 24), Helena founded the city and called it Helenopolis for no other reason than that St. Lucian was buried there. In Cyril Mango's interpretation (C. MANgo, The Empress Helena, Helenopolis, Pylae, TM 12, 1994, p. 147), that surely implies that in the eyes of Philostorgius Helena had not been born there.

${ }^{14}$ Socrates, Historia ecclesiastica, I, 17, 1, p. 55. Rufinus of Aquileia also mentions the vision (divinis admonita visionibus - Rufinus Aquileiensis, Historia ecclesiastica, X, 7, p. 969), and Ambrose of Milan (Ambrosius Mediolanensis, De obitu Theodosi, 43, p. 42) writes about inspiration from the Holy Ghost (infudit ei spiritus).

${ }^{15}$ There is no scholarly consensus regarding the date of her journey to Jerusalem. Cf. H.A. PoHLSander, Helena..., p. 84-85. Some scholars date it to 324-325 (S. Borgehammar, How the Holy Cross..., p. 137-140), others to the spring of 327 AD (E.D. HunT, Holy Land Pilgrimage in the Later Roman Empire AD 312-360, Oxford 1982, p. 28-49; J.W. Drijvers, Helena Augusta..., p. 55-72).

${ }^{16}$ Socrates, Historia ecclesiastica, I, 17, 1, p. 55. Eusebius of Caesarea (Eusebius Caesariensis, Vita Constantini, III, 25-28, p. 94-96) called the sepulchre of Christ the blessed place of Saviour's

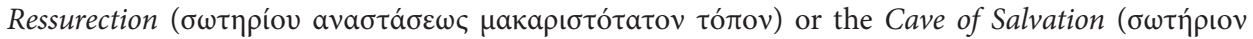

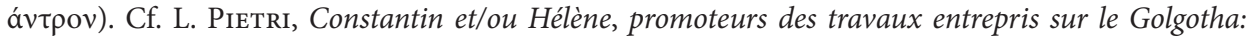
les comptes rendus des historiens ecclésiatiques grecs du V siècle, [in:] Historiographie de l'Église des premiers siècles, ed. B. Pouderon, Y.-M. Duval, Paris 2001, p. 371-380; E.D. Hunt, Constantine and Jerusalem, JEH 48, 1997, p. 405-424.

${ }^{17}$ Socrates, Historia ecclesiastica, I, 17, 2, p. 55.

${ }^{18}$ The first reference to the discovery of the True Cross in Jerusalem during Constantine's reign is found in a letter from Cyril of Jerusalem to emperor Constantius II, cf. E. BiHAIN, L'épitre de Cyrille de Jérusalem à Constance sur la vision de la croix (BGH 413), B 43, 1973, p. 287. Until recently, it was believed that the first to write about finding of the Holy Cross was the above-mentioned Gelasius of Caesarea, from whose Ecclesiastical history Socrates would have drawn his information about the legend of Helena. Cf. J.W. Drijvers, Helena Augusta..., p. 96-99; S. Borgehammar, How the Holy Cross..., p. 26-29. This notion was rejected by P. van Nuffelen (Gélase de Césarée..., p. 630). S. HeID (Der Ursprung der Helenalegende im Pilgerbetrieb Jerusalem, JAC 32, 1989, p. 62) draws attention to the role of pilgrims in the Holy Land in spreading the legend. Concerning the history of research on the legend of the inventio crucis, cf. The Finding of the True Cross the Judas Kyriakos Legend in syriac, ed. H.J.W. Drijvers, J.W. Drijvers, Louvain 1997, p. 17-20; M. van Esbroeck, Hélène à Edesse et la Croix, [in:] After Bardaisan. Studies on Continuity and Change in Syriac Christianity in Honour of Prof. Han J. W. Drijvers, ed. G.J. Reinink, A.C. KLUgkist, Leuven 1999, p. 107-115. ${ }^{19}$ Socrates does not use the name Golgotha when referring to Christ's Sepulchre. On its use in the literature of the $4^{\text {th }}$ century, cf. J.E. TAYlor, Christians and the Holy Place, Oxford 1993, p.120-121.

${ }^{20}$ According to Socrates (Historia ecclesiastica, I, 17, 2, p. 55), pagans had covered the Tomb of Christ with earth and built a temple devoted to Aphrodite at the site, placing her statue inside. An 
is a key figure in the further part of Socrates' account. It was she who learnt about the deeds of pagans, who had built a statue of Aphrodite at the place; she ordered it removed and the sepulchre unearthed. It was she who finally found three crosses there, one of which had belonged to the Saviour, and the other two to the villains crucified with $\mathrm{Him}^{21}$. God himself indicated which of the three crosses belonged to Christ by curing a dying woman with its touch ${ }^{22}$. Helena divided the relics of the Holy Cross, which she had obtained in a quite miraculous way, into parts. One of them was, in accordance with her wish, placed in a silver reliquary and remained in Jerusalem; another was sent to her son, Constantine, so that he could include it in his statue on the top of the Porphyry Column at the centre of the Forum of Constantine, which became a palladium ensuring the eternal existence of the city ${ }^{23}$. The empress also sent her son the nails with which Christ had supposedly been fastened to the Cross; Constantine used them as an element of his protective armour $^{24}$. Socrates emphasizes the fact that Helena commissioned the construction of a number of churches in Palestine, such as the Church of the Holy Sepulchre, the Church of the Nativity in Bethlehem and the Church on the Mount of Olives ${ }^{25}$. As pointed out by the historian, all of the building materials were provided by the emperor, who even urged Macarius, bishop of Jerusalem, to accelerate the construction works ${ }^{26}$.

earlier account of this comes from Eusebius of Caesarea (Eusebius CAEsARIEnsis, Vita Constantini, III, 26, 3, p. 95). On the buildings on Golgotha after the Bar Kochba Revolt, cf. S. GiBson, J.E. TAYLOR, Beneath the Church of the Holy Sepulchre. The Archaeology and Early History of Traditional Golgotha, London 1994, p. 68-69.

${ }^{21}$ Socrates, Historia ecclesiastica, I, 17, 3, p. 56. The relics of the Holy Cross were probably found in the third decade of the $4^{\text {th }}$ century, but the tradition associating their discovery with Helena is several dozen years later, cf. J.W. Drijvers, Helena Augusta..., p. 89, 93; S. Borgehammar, How the Holy Cross..., p. 31-53. B. BAERT, A Heritage of Holy Wood. The Legend of the True Cross in Text and Image, Leiden - Boston 2004, p. 23-37.

${ }^{22}$ Socrates, Historia ecclesiastica, I, 17, 5-6, p. 56. According to Ambrose of Milan (Ambrosius Mediolanensis, De obitu Theodosi, 45, p. 42-44) the identification of the Holy Cross was possible thanks to the plate with Christ's accusation (titulus). Socrates also mentions its discovery (I, 17, 4, p. 56), as does Rufinus of Aquileia (Rufinus Aquileiensis, Historia ecclesiastica, X, 7, p. 969), joining the two traditions concerning distinguishing the True Cross from the crosses of the villains: the use of the titulus and the miraculous recovery. Rufinus, according to S. HeID (Der Ursprung der Helenalegende..., p. 70), relied directly on the text of Ambrose.

${ }^{23}$ Socrates, Historia ecclesiastica, I, 17, 8, p. 56-57. Cf. S. Bralewski, The Porphyry Column in Constantinople and the Relics of the True Cross, SCer 1, 2011, p. 87-100.

${ }^{24}$ Socrates, Historia ecclesiastica, I, 17, 10, p. 57.

${ }^{25}$ Socrates, Historia ecclesiastica, I, 17, 7; 11, p. 57. Eusebius of Caesarea (Eusebius Caesariensis, Vita Constantini, III, 43, 1-4, p. 101-102) only attributes the foundation of two churches to Helena: one in Bethlehem and another on the mount of the Ascension of Jesus (the Mount of Olives), although he ascribes the discovery of the appropriate places for their construction to the emperor (III, 41, p. 101). ${ }^{26}$ Socrates, Historia ecclesiastica, I, 17, 10, p. 57. Eusebius of Caesarea includes a letter from the emperor to Macarius concerning this matter in the Vita Constantini (III, 30-32, p. 97-99). It only mentions the basilica that the emperor ordered to be built at the site of Christ's Passion. 
The historian emphasizes the great piety with which the ruler's mother got involved in the foundations. At the same time, however, she did not feel superior to others, as is indirectly pointed out by Socrates in a fragment describing her prayers among other women ${ }^{27}$. Her modesty and humility disposed her to organise feasts for sacred virgins, during which she would serve them at the table. She was also said to take care of churches and the poor, often supporting them with donations. Socrates considers her whole life to have been pious $(\varepsilon \dot{v} \sigma \varepsilon \beta \tilde{\omega} \varsigma)^{28}$. He adds that after her death, she was buried among emperors in imperial Rome ${ }^{29}$.

The information about Helena provided by Hermias Sozomen seems to be very similar; in fact, however, the historian introduced some significant changes compared with Socrates's account. First of all, it was Constantine who initiated the construction of the church in Jerusalem, near Golgotha, as a votive offering for the unification of the Church after the Council of Nicaea and as an expression of gratitude for blessings received by himself, his children and the state. The empress, at this time, only went to Jerusalem on a pilgrimage, in order to pray and visit the sacred places of the area ${ }^{30}$. Thus, according to Sozomen, her journey harmonized with the emperor's activities aimed at showing gratitude towards God for all the blessings he had received. This account is compatible with the information on this topic supplied by Eusebius of Caesarea ${ }^{31}$. Sozomen emphasizes that the excavations in search of the sepulchre of Christ were commissioned by the emperor and that they resulted in the discovery of the relics of the Cross. Thus, the historian



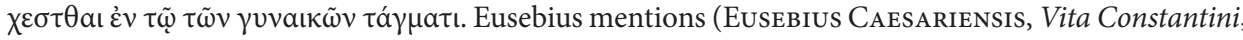
III, 45, p. 103) that the empress could be seen dressed very modestly, mingling with the crowd.

${ }^{28}$ Socrates, Historia ecclesiastica, I, 17, 13, p. 57.

${ }^{29}$ Socrates, Historia ecclesiastica, I, 17, 13, p. 57. Eusebius (Eusebius Caesariensis, Vita Constantini, III, 47, 1, p. 103) does not specify the name of the place where Helena was buried, only mentioning that her funeral took place in an imperial city. Concerning Helena's death and burial site, cf. J. Wortley, The "Sacred Remains" of Constantine and Helena, [in:] Byzantine narrative. Papers in honour of Roger Scott, ed. J. Burke, U. Betka, P. Buckley, K. Hay, R. Scott, A. Stephenson, Melbourne 2006 [= BAus, 16], p. 362-367.

${ }^{30}$ Sozomenus, Historia ecclesiastica, II, 1, 1-2, p. 47.

${ }^{31}$ According to Guy Sabbah, Eusebius of Caesarea (Eusebius Caesariensis, Vita Constantini, III, 42,1, p. 101) shows that Helena was ordered by the emperor to inspect the eastern Churches. In fact, Constantine's biographer only wrote about her journey to the eastern provinces, during which she visited cities and people in the splendour of imperial authority - $\mu \varepsilon \gamma a \lambda$ o (III, 44, p. 102). Still, it was her own initiative, motivated by her piety and her sense of duty, to give thanks to God on behalf of her son and grandchildren. To H.A. Pohlsander (Helena..., p. 84), Eusebius's account proves that Helena undertook this pilgrimage not as a private person but as the representative of her son and as Augusta. Cf. also: J.W. Drijvers, Helena Augusta..., p. 67. For A. Piganiol (L'Empire chrétien (325-395), ed. A. Chastagnol, Paris 1972, p. 39); H. CHadwick (The Fall of Eusthatius of Antioch, JTS 49, 1948, p. 32-33); T.D. BARNEs (Constantine and Eusebius, Cambridge 1981, p. 221) and E.D. HunT (Holy Land..., p. 33-34) the pilgrimage of the empress - who was involved in the assassination of Fausta, the wife of Constantine - was of an expiatory nature.
} 
does not attribute their recovery directly to the empress. Again, he corrects the account provided by Socrates by relying on the chronicle of Eusebius of Caesarea. According to the latter, the emperor, inspired by the Saviour, understood it as his duty to build a house of worship at the site of God's Resurrection in Jerusalem, in order to make it renowned and praiseworthy ${ }^{32}$.

From his chronicle, it can be concluded that the search for the wood of the Cross was Helena's idea; according to the historian, the empress was so zealous about the Christian teachings that there was nothing she desired more than finding the rel$\mathrm{ics}^{33}$. Sozomen did, however, express the belief that God indicated the place where the searches should be carried out through miraculous signs and dreams ${ }^{34}$, but he did not associate them directly with Helena. Similarly, the emperor's mother was merely an assistant of Macarius, the bishop of Jerusalem, when he tested the recovered crosses by touching the seriously ill woman with them ${ }^{35}$. Under Sozomen's account, Helena did not participate directly in the division of the uncovered relics, but only took some of them to her $\operatorname{son}^{36}$. Although Sozomen, unlike Socrates, does not attribute the construction of the Golgotha temple to her, he points out - relying on the account by Eusebius of Caesarea ${ }^{37}$ - that she had built two other churches in Bethlehem and on the Mount of Olives ${ }^{38}$. Even more than Socrates,

\footnotetext{
32 Eusebius Caesariensis, Vita Constantini, III, 25, p. 95. L. Pietri (Constantin et/ou Hélène..., p. 371-380) supposes that the accounts of Socrates, Sozomen and Theodoret about Helena depend on two traditions. One was based on the information found in the Vita Constantini by Eusebius of Caesarea, while the other stemmed from Jerusalem and was associated with a number of testimonies - by Cyril of Jerusalem (Cyrillus Hierosolymitanus, Epistula ad Constantiam imperatorem, [in:] E. Bihain, L'épître de Cyrille de Jérusalem à Constance sur la vision de la croix (BGH 413), B 43, 1973, p. 286-291; and catechesis bishop: 4, 10, 13), John Chrysostom (Joannes ChrysostoMos, In Iohannem Homiliae, 85, ed. J.-P. Migne, Paris 1862, col. 461 [= PG, 59]), Ambrose of Milan (Ambrosius Mediolanensis, De Obitu Theodosi, 43-48, p. 42-47) and Paulinus of Nola (Paulinus Nolanus, Epistulae, 31, p. 267-275). According to the former one, the instigator of the work undertaken on Golgotha was Constantine; according to the latter one, it was Helena.

${ }^{33}$ Sozomenus, Historia ecclesiastica, II, 1, 2, p. 47. It is noteworthy that Eusebius of Caesarea does not mention the recovery of the relics of the Cross at all. On this issue, cf. J.W. DrIJvers, Helena Augusta..., p. 83-89; H.A. Drake, Eusebius on the True Cross, JEH 36, 1985, p. 1-22; S. BorgeHammar, How the Holy Cross..., p. 116-117. According to Jan Pollok (Narodziny koncepcji "Ziemi Świętej”. Palestyna w teologicznej refleksji Euzebiusza z Cezarei i Cyryla Jerozolimskiego, [in:] Chrześcijaństwo u schyłku starożytności. Studia źródłoznawcze, ed. T. DerdA, E. WipszycKa, Warszawa 1997, p. 99-122), at the end of his life Eusebius began to consider some of the places connected with the activity of Christ holy, to which the discovery of the Lord's Tomb and the True Cross by Helena was also linked. According to B. BAert (A Heritage of Holy Wood..., p. 41), Eusebius perceived the Cross not as a relic but as a symbol (tropaion, vexillum): a triumph over the pagans on the one hand (as Constantine also used it) and a triumph over death on the other (the Resurrection).

${ }^{34}$ Sozomenus, Historia ecclesiastica, II, 1, 4, p. 48.

${ }^{35}$ Sozomenus, Historia ecclesiastica, II, 1, 7, p. 49.

${ }^{36}$ Sozomenus, Historia ecclesiastica, II, 1, 8-9, p. 49.

${ }^{37}$ Eusebius Caesariensis, Vita Constantini, III, 43, p. 101-102.

${ }^{38}$ Sozomenus, Historia ecclesiastica, II, 2, 1, p. 50.
} 
Sozomen highlights Helena's piety and godliness, demonstrated on numerous occasions. As an example, he mentions her service during feasts for sacred virgins, also described by Socrates. However, Sozomen develops his predecessor's description and points out, following Rufinus of Aquileia ${ }^{39}$, that Helena would fulfil the role of a servant during the feast, serving dishes, pouring water for cleaning hands and performing other duties characteristic of the waiting staff ${ }^{40}$. While Socrates writes about such feasts in the plural, Sozomen speaks of one particular supper during the empress's visit to Jerusalem, just like Rufinus of Aquileia describes one such deed of Constantine's mother ${ }^{41}$.

In addition to this fragment, Sozomen, in comparison with Socrates, enhances the information about Helena's other charitable deeds that she performed during the aforementioned visit to the cities in the East. Sozomen, following Eusebius ${ }^{42}$, stresses that Helena received from her son the authority to use the imperial treasury freely ${ }^{43}$, a fact not included in Socrates' account. On the one hand, it proves Constantine's trust in Helena; on the other hand, it also enabled her to develop her charity work. Thus, according to Sozomen's account, the empress honoured some of the local churches with appropriate votive offerings, she made many poor people wealthy, donated ample food supplies to the starving and liberated a number of convicts from a long prison sentences, exile or labour in mines ${ }^{44}$. These offerings corresponded to Constantine's intention to repay God for all the blessings he had received along with his family and the whole country. One of the means by which he intended to accomplish this was to build the basilica on Mount Golgotha. The others were acts of mercy shown to the impoverished, those suffering from famine and even those convicted to exile, imprisonment or devastating labour in mines. By mentioning Helena's access to the imperial treasury, Sozomen suggests that the virtue of showing generosity to the subjects stemmed from Constantine himself. Either way, there emerges a picture of a woman sensitive to people's suffering, doing her best to help them.

In the final conclusions concerning the empress' life, Sozomen states that it could not have been lived better, since she spent it in the absolutely optimal way. She also received due reward during her earthly life, when she was proclaimed Augusta and her image was imprinted on gold coins. Even her death was glorious, as she lived to be around 80 years old, a fact emphasized by Socrates. Sozomen, unlike his predecessor, stressed that upon her death, she left her son together with her grandsons, the caesars, ruling over the whole united Roman Empire. The expression she left her son means that he perceived the unification of the Imperium

\footnotetext{
${ }^{39}$ Rufinus Aquileiensis, Historia ecclesiastica, X, 8, p. 970-971.

${ }^{40}$ Sozomenus, Historia ecclesiastica, II, 2, 2, p. 50. Cf. H. Leppin, Von Constantin..., p. 165.

${ }^{41}$ Rufinus Aquileiensis, Historia ecclesiastica, X, 8, p. 970-971.

${ }^{42}$ Eusebius Caesariensis, Vita Constantini, III, 47, 3, p. 103.

${ }^{43}$ Sozomenus, Historia ecclesiastica, II, 2, 4, p. 51.

${ }^{44}$ Sozomenus, Historia ecclesiastica, II, 2, 3, p. 50-51.
} 
Romanum under the reign of her descendants as a result of her pious life. In accordance with what the Ecclesiastical History says concerning God's blessings being brought about by the devoutness of the rulers, the effect of Helena's piety is seen as procuring the prosperity of the united, internally peaceful empire and the success of her family - her son reigned over a huge country in alliance with her grandsons. According to Sozomen, Helena was appropriately commemorated, since as many as two cities - one in Bithynia and another in Palestine - had been named in her honour. In this fragment, Sozomen also complemented Socrates' account, which only mentions one city honoured in this way.

In his Ecclesiastical history, Socrates depicts Helena as a pious, strong and independent woman, the mother of the emperor, realizing her own ideas and acting as a tool in the hands of God - the ultimate inspiration of her actions. The emperor, her son, only supported her in her undertakings. According to Socrates, Helena travelled to Jerusalem to answer God's call; there, she organized the search for the Sepulchre and the Holy Cross and found them. She was supported by Macarius, the bishop of Jerusalem, who, after God's intervention, distinguished the True Cross from the crosses of the two villains. The empress divided the relics and sent some of them to her son to Constantinople; moreover, in the Holy Land, she built three basilicas connected with the life of Christ. Finally, Socrates mentions her piety and discusses the place of her burial. Conversely, in Sozomen's account of the recovery of Christ's Sepulchre and the relics, the main role is played by emperor Constantine, who wished to repay God for his blessings; he ordered the search and the construction of the basilica on Mount Golgotha. His mother only supported him in his plans, led by her devoutness, to which Sozomen pays more attention than his predecessor - he emphasizes Helena's sensitivity to human poverty and suffering. The emperor was also involved in her generous deeds and gave her access to the imperial treasury. Thus, as indicated by Sozomen, Helena's piety brought prosperity both to her family and to the whole Roman Empire.

\section{Bibliography}

\section{Sources}

Ambrosius Mediolanensis, De obitu Theodosi, ed. A. KotŁowska, K. Ilski, Poznań 2008.

Cyrillus Hierosolymitanus, Epistula ad Constantiam imperatorem, [in:] E. Bihain, L'épître de Cyrille de Jérusalem à Constance sur la vision de la croix (BGH 413), B 43, 1973, p. 286-291.

Eusebius Caesariensis, Vita Constantini, ed. F. Winkelmann, Berlin-New York 2008 [= Die griechischen christlichen Schriftsteller der ersten [drei] Jahrhunderte, 7].

Gelasius Cyzicenus, Historia ecclesiastica, ed. M. Heinemann, G. Loeschcke, Leipzig 1918 [= Die griechischen christlichen Schriftsteller der ersten [drei] Jahrhunderte, 28]. 
Ioannes Chrysostomos, In Iohannem Homiliae, ed. J.-P. Migne, Paris 1862, col. 23-485 [= Patrologiae cursus completus, Series graeca, 59].

Paulinus Nolanus, Epistulae, ed. G. De Hartel, Vindobonae 1894 [= Corpus scriptorum ecclesiasticorum latinorum, 29].

Philostorgius, Historia ecclesiastica, ed. I. Bidez, F. Winkelmann, Berlin 1981 [= Die griechischen christlichen Schriftsteller der ersten [drei] Jahrhunderte, 21].

Procopius, De aedificiis, ed. H.B. Dewing, G. Downey, London 1940.

Rufinus Aquileiensis, Historia ecclesiastica, ed. E. Schwartz, T. Mommsen, F. Winkelmann, Berlin 1999 [= Die griechischen christlichen Schriftsteller der ersten [drei] Jahrhunderte, Neue Folge, 6].

Sozomenus, Historia ecclesiastica, ed. I. Bidez, G.Ch. Hansen, Berlin 1995 [= Die griechischen christlichen Schriftsteller der ersten [drei] Jahrhunderte, Neue Folge, 4].

Sozomène, Histoire Ecclésiastique, vol. I-II, ed. B. Grillet, G. Sabbah, Paris 1983 [= Sources chrétiennes, 306].

Socrates, Historia ecclesiastica, ed. G.C. HANSEn, Berlin 1995 [= Die griechischen christlichen Schriftsteller der ersten [drei] Jahrhunderte, Neue Folge, 1].

Socrate de Constantinople, Histoire ecclésiastique, ed. G.C. Hansen, P. Périchon, P. Maraval, Paris 2004 [= Sources chrétiennes, 477].

Theodoretus Cyrensis, Historia ecclesiastica, ed. L. Parmentier, G.Ch. Hansen, Berlin-New York 2009 [= Die griechischen christlichen Schriftsteller der ersten [drei] Jahrhunderte, Neue Folge, 5].

\section{Secondary Literature}

Barnes T.D., Athanasius and Constantius. Theology and Politics in the Constantinian Empire, Cambridge 1993.

Barnes T.D., Constantine and Eusebius, Cambridge 1981.

Baert B., A Heritage of Holy Wood. The Legend of the True Cross in Text and Image, Leiden-Boston 2004.

BiHAIn E., L'épître de Cyrille de Jérusalem à Constance sur la vision de la croix (BGH 413), "Byzantion. Revue internationale des études byzantines" 43, 1973, p. 264-296.

Borgehammar S., How the Holy Cross was found. From Event to Medieval Legend, Stockholm 1991.

Bralewski S., Obraz papiestwa w historiografii kościelnej wczesnego Bizancjum, Łódź 2006.

Bralewsin S., The Porphyry Column in Constantinople and the Relics of the True Cross, "Studia Ceranea. Journal of the Waldemar Ceran Research Center for the History and Culture of the Mediterranean Area and South-Eastern Europe" 1, 2011, p. 87-100.

Brubaker L., Memories of Helena. Patterns in Imperial Female Matronage in the Fourth and Fifth Centuries, [in:] Women, Men and Eunuchs. Gender in Byzantium, ed. L. James, London-New York 1997, p. 52-75.

Brzozowska Z.A., Ideał chrześcijańskiego władcy - św. św. Konstantyn i Helena w kulturze duchowej i politycznej Bizancjum (337-843 r.), “Teka Historyka” 36/37, 2009, p. 152-164.

Снadwick H., The Fall of Eusthatius of Antioch, "The Journal of Theological Studies" 49, 1948, p. 27-35.

Charlesworth M.P., The Virtues of a Roman Emperor: Propaganda and the Creation of Belief, "Proceedings of the British Academy" 23, 1937, p. 105-133. 
Chesnut G.F., The First Christian Histories. Eusebius, Socrates, Sozomen, Theodoret, and Evagrius, Paris 1977.

Couzard R., Sainte Hélène d'après l'histoire et la tradition, Paris 1911.

Drake H.A., Eusebius on the True Cross, "Journal of Ecclesiastical History" 36, 1985, p. 1-22.

Drijvers J., Helena Augusta, the Mother of Constantine the Great and the Legend of Her Finding of the Cross, Leiden-New York-København-Köln 1992.

Esbroeck M. van, Hélène à Edesse et la Croix, [in:] After Bardaisan. Studies on Continuity and Change in Syriac Christianity in Honour of Prof. Han J. W. Drijvers, ed. G.J. ReInINK, A.C. KLugKIST, Leuven 1999, p. 107-115.

FEARS J.R., The cult of Virtues and Roman Imperial Ideology, [in:] ANRW, vol. II.17.2, Berlin-New York 1981, p. 827-948.

The Finding of the True Cross the Judas Kyriakos Legend in syriac, ed. H.J.W. DrIJvers, J.W. DrIJvers, Louvain 1997.

Fros H., Święta Helena, Kraków 1995.

Gibson S., TAYlor J.E., Beneath the Church of the Holy Sepulchre. The Archaeology and Early History of Traditional Golgotha, London 1994.

Glas A., Die Kirchengeschichte des Gelasios von Kaisareia, die Vorlage für die beiden letzten Bücher der Kirchengeschichte Rufinus, Leipzig-Berlin 1914.

Hansen G.C., Mutmassungen über die Kirchengeschichte des Sokrates, "Zeitschrift für antikes Christentum" 3, 1999, p. 278-285.

HeId S., Der Ursprung der Helenalegende im Pilgerbetrieb Jerusalem, "Jahrbuch für Antike und Christentum" 32, 1989, p. 41-71.

Hunt E.D., Constantine and Jerusalem, "Journal of Ecclesiastical History" 48, 1997, p. 405-424.

Hunt E.D., Holy Land Pilgrimage in the Later Roman Empire AD 312-360, Oxford 1982.

Janiszewski P., Żywioły w stużbie propagandy, czyli po czyjej stronie stoi Bóg. Studium klęsk i rzadkich fenomenów przyrodniczych u historyków Kościoła w IV i V w., [in:] Chrześcijaństwo u schyłku starożytności. Studia źródłoznawcze, ed. T. Derda, E. WipszycKa, vol. III, Kraków 2000.

Lauer H.H., Kaiserin Helena. Leben und Legenden, München 1967.

Leppin H., Von Constantin dem Grossen zu Theodosius II. Das christliche Kaisertum bei den Kirchenhistorikern Socrates, Sozomenus und Theodoret, Göttingen 1996.

Leszka M.B., Helena - matka Konstantyna Wielkiego, "Mówią Wieki” 2002, 4, p. 30-32.

Liebeschuetz J.H.W.G., Ecclesiastical Historians on Their Own Times, "Studia Patristica” 34, 1993, p. $151-163$.

Mango C., The Empress Helena, Helenopolis, Pylae, "Travaux et mémoires du Centre de recherches d'histoire et civilisation byzantines" 12, 1994, p. 143-158.

Maurice J., Sainte Hélène, Lille 1927.

Nuffelen P. van, Un Héritage de Paix et de Piété. Étude sur les histoires ecclésiastiques de Socrate et de Sozomène, Leuven-Paris-Dudley 2004.

Nuffelen P. van, Gélase de Césarée, Un compilateur du cinquième siècle, "Byzantinische Zeitschrift" 95.2, 2002, p. 621-639.

Piganiol A., L'Empire chrétien (325-395), ed. A. Chastagnol, Paris 1972.

Pietri L., Constantin et/ou Hélène, promoteurs des travaux entrepris sur le Golgotha: les comptes rendus des historiens ecclésiatiques grecs du Ve siècle, [in:] Historiographie de l'Église des premiers siècles, ed. B. Pouderon, Y.-M. Duval, Paris 2001, p. 371-380. 
Pohlsander H.A., Helena. Empress and Saint, Chicago 1995.

Pollok J., Narodziny koncepcji “Ziemi Świętej”. Palestyna w teologicznej refleksji Euzebiusza z Cezarei i Cyryla Jerozolimskiego, [in:] Chrześcijaństwo u schyłku starożytności. Studia źródłoznawcze, ed. T. Derda, E. Wipszycka, Warszawa 1997, p. 99-122.

Rouillon A.-M., Sainte Hélène, Paris 1908.

Szymański A., Św. Helena cesarzowa, Poznań 1933.

TAYLOR J.E., Christians and the Holy Place, Oxford 1993.

Urbainczy T., Observations on the differences between the Church Histories of Socrates and Sozomen, "Historia. Zeitschrift für alte Geschichte" 46, 1997, p. 355-373.

Urbainczy T., Socrates of Constantinople. Historian of Church and State, Michigan 1997.

Young F., From Nicaea to Chalkedon, London 1983.

Vatchrova V., (Saint) Helena of Sofia. The Evolution of the Memory of Saint Constantine's Mother, [in:] The Reception of Byzantium in European Culture since 1500, ed. D. Smyth, P. MarciniaK, Farnham 2016, p. 81-96.

Wallace-Hadrill A., The Emperor and His Virtues, "Historia. Zeitschrift für alte Geschichte" 30, 1981, p. 298-323.

Wallraff M., Der Kirchenhistoriker Sokrates. Untersuchungen zu Geschichtsdarstellung, Methode und Person, Göttingen 1997.

Winkelmann F., Das Problem der Rekonstruktion der Historia ecclesiastica des Gelasius von Caesarea, "Forschungen und Fortschritte" 10, 1964, p. 311-314.

Winkelmann F., Untersuchungen zur Kirchengeschichte des Gelasios von Kaisareia, Berlin 1966 [= Sitzungsberichte der Deutschen Akademie der Wissenschaften zu Berlin. Klasse für Sprachen, Literatur und Kunst, 3].

Winkelmann F., Charakter und Bedeutung der Kirchengeschichte des Gelasios von Kaisareia, "Byzantinische Forschungen. Internationale Zeitschrift für Byzantinistik" 1, 1966, p. 346-385.

Wojciechowski L., Drzewo przenajszlachetniejsze. Problematyka Drzewa Krzyża w chrześcijaństwie zachodnim (IV-połowa XVII w.). Od legend do kontrowersji wyznaniowych i piśmiennictwa specjalistycznego, Lublin 2003.

Wortley J., The "Sacred Remains" of Constantine and Helena, [in:] Byzantine narrative. Papers in honour of Roger Scott, ed. J. Burke, U. Betka, P. Buckley, K. Hay, R. Scott, A. Stephenson, Melbourne 2006 [=Byzantina Australiensia, 16], p. 351-367.

Zwolski E., Helena, matka Konstantyna Wielkiego w świetle historii, “Zeszyty Naukowe KUL” 5, 1962, p. 53-76.

Abstract. In his Ecclesiastical history, Socrates depicts Helena as a pious, strong and independent woman, the mother of the emperor, realizing her own ideas and acting as a tool in the hands of God - the ultimate inspiration of her actions. The emperor, her son, only supported her in her undertakings. According to Socrates, Helena travelled to Jerusalem to answer God's call; there, she organized the search for the Sepulchre and the Holy Cross and found them. She was supported by Macarius, the bishop of Jerusalem, who, after God's intervention, distinguished the True Cross from the crosses of the two villains. The empress divided the relics and sent some of them to her son to Constantinople; moreover, in the Holy Land, she built three basilicas connected with the life of Christ. Finally, Socrates mentions her piety and discusses the place of her burial. Conversely, in Sozomen's account of the recovery of Christ's Sepulchre and the relics, the main role is played by emperor Constantine, 
who wished to repay God for his blessings; he ordered the search and the construction of the basilica on Mount Golgotha. His mother only supported him in his plans, led by her devoutness, to which Sozomen pays more attention than his predecessor - he emphasizes Helena's sensitivity to human poverty and suffering. The emperor was also involved in her generous deeds and gave her access to the imperial treasury. Thus, as indicated by Sozomen, Helena's piety brought prosperity both to her family and to the whole Roman Empire.

Keywords: Helena, Constantine the Great, Socrates, Sozomen, Holy Cross

\section{Sławomir Bralewski}

Uniwersytet Łódzki

Wydział Filozoficzno-Historyczny Instytut Historii

Katedra Historii Bizancjum

ul. Kamińskiego 27a

90-219 Łódź, Polska/Poland sbralewski@o2.pl 